\title{
Latitudinal trends in habitat quality of shallow-water flatfish nurseries
}

\author{
Vânia Freitas ${ }^{1,2, *}$, Sebastiaan A. L. M. Kooijman ${ }^{3}$, Henk W. van der Veer ${ }^{1}$ \\ ${ }^{1}$ Royal Netherlands Institute for Sea Research, PO Box 59, 1790 AB Den Burg, Texel, The Netherlands \\ ${ }^{2}$ Centro Interdisciplinar de Investigação Marinha e Ambiental (CIIMAR), Universidade do Porto, \\ Rua dos Bragas 289, 4050-123 Porto, Portugal
}

${ }^{3}$ Department of Theoretical Biology, Vrije Universiteit, de Boelelaan 1087, 1081 HV Amsterdam, The Netherlands

\begin{abstract}
The habitat quality of European shallow-water nurseries was studied for 3 common flatfish species based on juvenile growth conditions. Field growth of 0-group plaice Pleuronectes platessa, flounder Platichthys flesus and sole Solea solea, from both published and unpublished studies, was compared with maximum growth predicted by a bioenergetics model based on the dynamic energy budget theory. In plaice and flounder, realized growth ratio decreased consistently during the growing season in most of the nurseries analyzed, indicating a widespread pattern of declining conditions. In sole, growth performance was not maximal, but as opposed to the other species, no clear temporal trend in realized growth ratio was observed. A latitudinal comparison of realized growth ratio over the various nurseries indicated clear positive trends for plaice and flounder, with better growth conditions at northern latitudes. In sole, despite some variability, the same trend was found during part of the summer. In the absence of clear gradients in benthic prey biomass, we hypothesize that increased food limitation in southern locations is most likely caused by interspecific competition reducing maximum individual intake rates. These results suggest that, in the context of global warming, habitat quality of southern European nurseries for juvenile growth may be particularly affected by the combined interaction of food and thermal constraints.
\end{abstract}

KEY WORDS: Plaice $\cdot$ Flounder $\cdot$ Sole $\cdot$ Growth potential $\cdot$ Dynamic energy budget $\cdot$ Temperature . Food limitation · Latitude

\section{INTRODUCTION}

Temperate estuarine and shallow coastal systems are key habitats in the context of life cycle closure in marine populations (sensu Sinclair 1988). For flatfish, these areas act as nurseries where the trade-off between growth and survival is optimized due to abundant food resources, few predators and favourable environmental conditions (Bergman et al. 1988b, Gibson et al. 2002). These specific habitat quality features in combination with the amount of area available have the potential to influence recruitment levels (Rijnsdorp et al. 1992, Gibson 1994, Van der Veer et al. 1994, 2000) and thus, over the years, there has been an increasing interest in better evaluating the function of nurseries (Vasconcelos et al. 2011). Although the production of juveniles to the adult populations has been suggested as the most integrative measure of the quality of juvenile habitats (Able et al. 1999, Beck et al. 2001), owing to problems in accurately estimating population sizes and their changes (Cowley \& Whitfield 2002), other indicators have been sought. Growth is inextricably linked to mortality in the early life stage, which is supported by the general inverse relationship between size of an individual fish and its risk of mortality (Zijlstra et al. 1982, Beverton \& Iles 1992, Sogard 1997). This has motivated the use of fish growth as a suitable index 
to assess habitat quality (Brandt 1993, Able et al. 1999, Le Pape et al. 2003, Amara et al. 2007).

Classical studies with flatfish have explored the ability of fish to achieve its maximum growth potential as a relative measure of its well-being and, indirectly, of the quality of their coastal nurseries (Zijlstra et al. 1982, Van der Veer 1986, Van der Veer et al. 1991, 2001a). While studies from the western Dutch Wadden Sea indicated that growth in the field was generally maximal during most of the nursery phase, research in other areas showed a slightly different picture, with increasing discrepancies between observed field growth during summer and maximum growth measured in the laboratory (Amara 2004, Hurst \& Abookire 2006, Freitas et al. 2010a). In plaice Pleuronectes platessa, such a trend was observed over a large latitudinal range from northern Norway estuarine waters (Freitas et al. 2010a), to the Irish Sea (Nash et al. 1994), and at Balgzand, in the Dutch Wadden Sea (Teal et al. 2008). Although this discrepancy suggested food limitation, an experimental bias could not be excluded since, in summer, fish size had outgrown the range where the maximum growth model could be applied (Van der Veer et al. 2010).

This impasse was recently solved with the use of a mechanistic growth model based on the dynamic energy budget (DEB) theory (Kooijman 2000, 2010). DEB models provide a benchmark for maximum growth potential that simultaneously considers both the internal state of the individual (structure, reserve) and external factors (e.g. food availability and temperature) affecting metabolism (Kooijman 2000). This modelling approach was applied to re-investigate 0-group plaice growth conditions in the Balgzand intertidal area (Van der Veer et al. 2010) and previous conclusions have been refined. Evidence from several years suggested a reduced habitat quality for plaice in summer, proposing competition with (or interference by) gobiidae and epibenthic crustaceans as the most likely underlying mechanism (Van der Veer et al. 2010).

At present, it is unclear to what extent these results for 0-group plaice at Balgzand are a general phenomenon present in more areas and whether other flatfish species exhibit similar patterns during their nursery phase. On the one hand, the same dominant mobile epibenthic fauna are present across temperate shallow-water systems (Pihl 1985, Maes et al. 1998, Amara \& Paul 2003, Freitas et al. 2010a) with annual density maxima in summer (Maes et al. 1998, Henderson et al. 2006, Viegas et al. 2007), which could indicate that similar processes are likely to take place regardless of the area considered. On the other hand, over a large spatial scale, different patterns could emerge due to variations in temporal utilization of the nursery by juvenile flatfish (e.g. timing of nursery colonization). At the interspecific level, differences in feeding and environmental preferences may also offset potential competitive effects.

We evaluated these hypotheses by comparing the conditions for growth in different flatfish species and various nurseries along their range of distribution. This study builds on the approach followed in Van der Veer et al. (2010) to study plaice growth conditions using bioenergetics modelling and expands the scope to 2 other flatfish species, sole Solea solea and flounder Platichthys flesus. These two species are also important components of demersal flatfish communities, overlapping with plaice in the use of coastal nursery grounds from Bay of Biscay to Western Scotland (Nielsen 1986, Quéro et al. 1986). As far north as the White Sea (Nielsen 1986), only plaice and flounder can be found, while in southern Europe, sole and flounder co-occur up to a latitude of $\sim 40^{\circ} \mathrm{N}$ (Vinagre et al. 2005).

\section{MATERIALS AND METHODS}

\section{Field data}

Basic data were collected from published and unpublished field studies describing juvenile flatfish growth in combination with local temperature conditions. Studies were selected to cover most of the species distribution ranges and those providing information for various species were particularly targeted. Information presented in graphical form (seasonal changes in mean total length and in water temperature) was scanned and digitalized using Grab-it! XP 10 software (Datatrend Software). Details on the sampling procedures of published data sets can be found in the papers (see Table 1 for references). In most areas sampling was performed with beam trawls (1 to $4 \mathrm{~m}$ ), but in very shallow waters push nets and drop traps were also used.

Temperature data were as much as possible taken from the original publications; however, in some cases other sources were used to complement the data. These included published studies reporting seasonal temperature patterns for the same areas and years of study or oceanographic databases available from national research or meteorological institutes (see Table 1 for sources). The temperature conditions in each location considered in this study are shown in Appendix 1 (Fig. A1). 
Table 1. Pleuronectes platessa, Platichthys flesus and Solea solea. Locations and original sources of the growth data of plaice flounder and sole used in the present analyses. Superscripts indicate additional temperature sources: ${ }^{1}$ Marine Research Institute (Station Reijkjavik; www.hafro.is/Sjora); ${ }^{2}$ Swedish Meteorological and Hydrological Institute (Station Alsbäck, Släggö; www.smhi.se); ${ }^{3}$ National Environmental Research Institute (MADS; Station Mariager Fjord, Dybet; www. dmu.dk/en/water/marinemonitoring/mads) ${ }_{i}^{4}$ Cabral \& Costa (2001)

\begin{tabular}{|c|c|c|c|}
\hline Location & Latitude & Species & Source \\
\hline Valosen, Norway & $67^{\circ} \mathrm{N}$ & P. platessa & Freitas et al. (2010a) \\
\hline Faxaflói ${ }^{1}$, SW Iceland & $64^{\circ} \mathrm{N}$ & P. platessa & Hjörleifsson \& Pálsson (2001) \\
\hline Gullmar Fjord ${ }^{2}$, Sweden & $58^{\circ} \mathrm{N}$ & P. platessa & L. Pihl unpubl. data \\
\hline Loch Ewe, Scotland & $57^{\circ} 50^{\prime} \mathrm{N}$ & P. platessa & $\begin{array}{l}\text { Steele \& Edwards (1970), } \\
\text { Edwards \& Steele (1968) }\end{array}$ \\
\hline Mariager Fjord ${ }^{3}$, Denmark & $56^{\circ} \mathrm{N}$ & P. flesus & Andersen et al. (2005) \\
\hline Port Erin Bay, Isle of Man, UK & $54^{\circ} \mathrm{N}$ & P. platessa & R. Nash unpubl. data \\
\hline Dollard estuary, eastern Dutch Wadden Sea & $53^{\circ} \mathrm{N}$ & $\begin{array}{l}\text { P. platessa } \\
\text { P. flesus } \\
\text { S. solea }\end{array}$ & Jager et al. (1995) \\
\hline Balgzand, western Dutch Wadden Sea & $53^{\circ} \mathrm{N}$ & $\begin{array}{l}P . \text { platessa } \\
P . \text { flesus } \\
\text { S. solea }\end{array}$ & $\begin{array}{l}\text { Van der Veer et al. (2010), present study } \\
\text { Van der Veer et al. (1991), present study } \\
\text { Van der Veer et al. (1991), present study }\end{array}$ \\
\hline Bay of Canche, NW France & $50^{\circ} 30^{\prime} \mathrm{N}$ & $\begin{array}{l}P . \text { platessa } \\
\text { S. solea }\end{array}$ & $\begin{array}{l}\text { Amara \& Paul (2003), Amara (2004) } \\
\text { Amara (2004) }\end{array}$ \\
\hline Minho Estuary, Portugal & $41^{\circ} \mathrm{N}$ & $\begin{array}{l}\text { P. flesus } \\
\text { S. solea }\end{array}$ & $\begin{array}{l}\text { Dolbeth et al. (2010), present study } \\
\text { Dolbeth et al. (2010), present study }\end{array}$ \\
\hline Mondego Estuary, Portugal & $40^{\circ} \mathrm{N}$ & $\begin{array}{l}\text { P. flesus } \\
\text { S. solea }\end{array}$ & $\begin{array}{l}\text { Martinho et al. (2008), Dolbeth et al. (2010) } \\
\text { Martinho et al. (2008), Dolbeth et al. (2010) }\end{array}$ \\
\hline Tagus Estuary ${ }^{4}$, Portugal & $39^{\circ} \mathrm{N}$ & S. solea & Cabral (2003) \\
\hline
\end{tabular}

Field growth rates were estimated based on reported increases in mean total length $\left(\mathrm{cm} \mathrm{d}^{-1}\right)$ of the entire population or specific age classes (or cohorts) between 2 successive sampling dates.

To avoid the confounding effects of migrations on growth estimates, in each data set only the period of linear increase in mean length was considered assuming that: (1) during settlement (spring-summer), length-frequency distributions are biased by the continuous arrival of small individuals, resulting in an underestimation of growth rates; and (2) at the end of the growing season (summer-autumn), as a result of sizedependent emigration, length-frequency data are biased by the decline in abundance of larger individuals, causing an apparent reduction in growth rates.

Negative daily growth rates were not considered. At the end, only those data sets with $>5$ growth rate estimates were used in subsequent analyses.

\section{DEB model-based growth potential}

Growth potential was determined based on the standard DEB model (Kooijman 2010). A thorough description of the model and relevant equations is given in Van der Veer et al. (2010; Eqs. 1-3). Maxi- mum food conditions were simulated in the model using the scaled functional response $(f)$, a dimensionless parameter ranging from 0 to 1 (ad libitum food) that relates ingestion to food density in the environment through a Holling type II functional response (Kooijman 2010). Under constant food conditions (or at abundant food due to the hyperbolic functional response), DEB differential equations can be analytically solved and the dynamics of growth then simplifies to Von Bertalanffy growth (Kooijman 2010).

Growth rates are affected not only by food availability but also by temperature conditions, due to the temperature dependence of physiological rates. In the DEB model, such thermal dependence is described using an Arrhenius-type relationship extended to account for the effects of temperature at both lower and upper tolerance boundaries (Kooijman 2010, p. 21; Van der Veer et al. 2010, Eq. 4).

\section{Realized growth ratio}

Field growth rates were compared with the DEBpredicted growth potential to evaluate the possibility of food limitation. Growth potential, defined as the 
maximum growth rate at constant and maximum food conditions ( $f=1)$, was determined for each growth interval using site-specific water temperatures.

DEB parameters were taken from Van der Veer et al. (2001b, 2009, 2010) and Freitas et al. (2010b). Before any simulations, the reliability of the model parameter values was validated by comparing model-predicted maximum growth rates with laboratory-derived maximum growth. For plaice and flounder, experimental growth data by Fonds et al. (1992) were used, while for sole, data were taken from Fonds \& Rijnsdorp (1988) and Irvin (1973 in Howell 1997).

Temperature parameters used to correct growth rates according to the extended Arrhenius relationship were also based on previous estimates (Freitas et al. 2010b) and in some further fine-tuning by comparing the shape of the growth curve predicted by the DEB model with the shape of those derived from experimental observations. For sole, Arrhenius temperature was changed from 8500 to $6500 \mathrm{~K}$ to better match the growth curves described by the 2 data sets available. Although growth rates described in Irvin's experiments are lower than those in Fonds \& Rijnsdorp (1988), both data sets show little increase in growth rates above $20-22^{\circ} \mathrm{C}$.

Due to gender-related differences in energy assimilation, some of the parameters differ (Freitas et al. 2010 b); therefore, maximum growth in relation to temperature was predicted for each sex separately. However, for comparison with field growth where sexes were not distinguished, DEB-predicted growth rates for females and males were averaged, assuming a 1:1 field sex ratio.

The fraction of maximum growth realized by juvenile fish of each species was estimated as the ratio between observed and DEB-predicted maximum growth (realized growth ratio [RG], dimensionless). Patterns in RG were analyzed over the growing season and compared among areas to assess trends with latitude. To help visualizing patterns in data, smoothing curves were added using the LOESS function in R (R Development Core Team 2009) and the fitted values in each month were plotted against latitude for each species.

\section{RESULTS}

\section{Field growth}

In total, reliable information could be collected from 11 areas ranging from northern Norway to the Portuguese coast (Table 1). In most cases, only studies of single species were available. Time coverage of the data sets varied from single to multiple years. Since interannual comparisons were outside the scope of this paper, data from different years were pooled.

Observed field growth rates showed high variability in all areas in the 3 species (Fig. 1). Flounder and plaice growth rates were mostly up to $0.10 \mathrm{~cm} \mathrm{~d}^{-1}$, with the exception of a few individual data points in the order of $0.13 \mathrm{~cm} \mathrm{~d}^{-1}$ for plaice in Swedish waters (Fig. 1a). In sole, maximum growth rates were between 0.15 and $0.20 \mathrm{~cm} \mathrm{~d}^{-1}$ reflecting higher growth potential compared with the other species (Fig. 1c). In all species, growth rates seem to decline
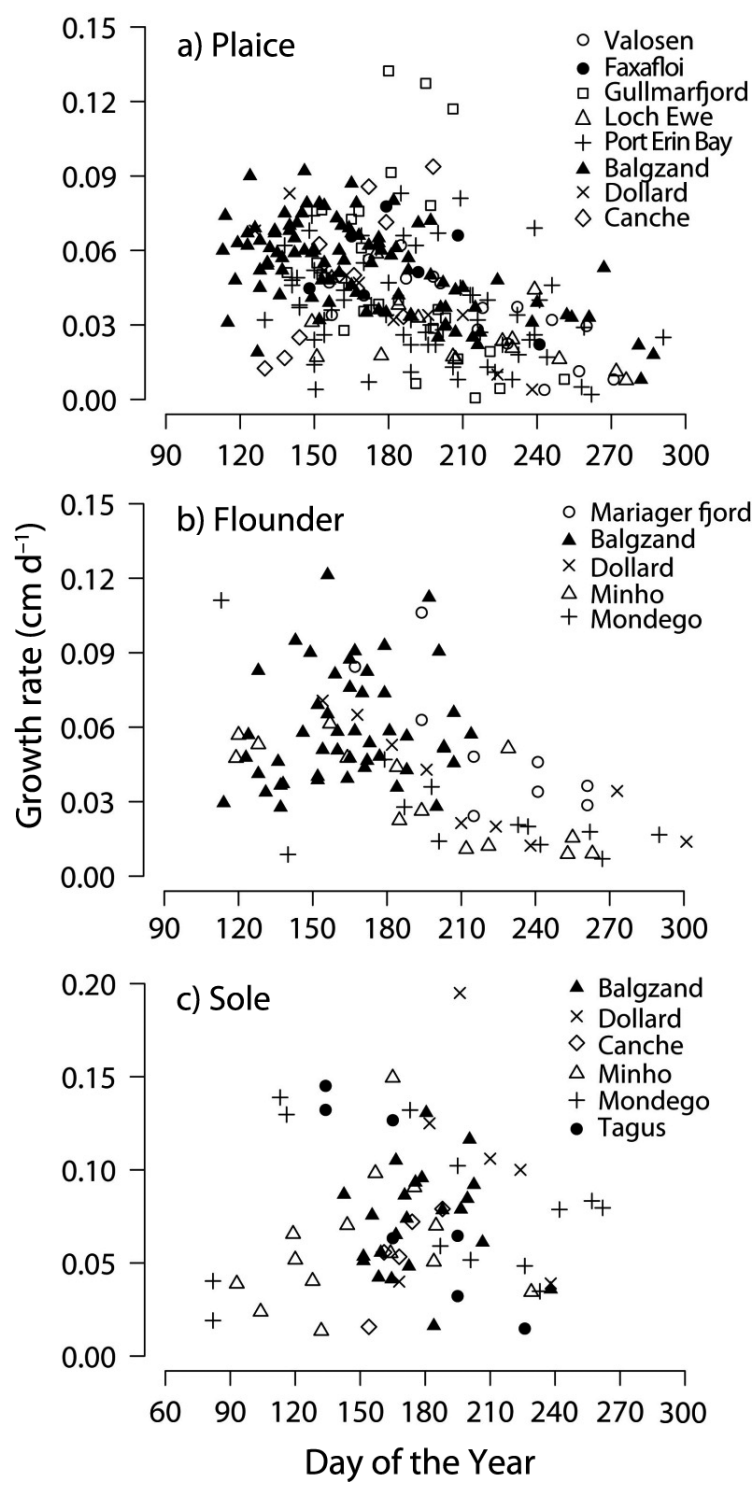

Fig. 1. Pleuronectes platessa, Platichthys flesus and Solea solea. Field growth rates $\left(\mathrm{cm} \mathrm{d}^{-1}\right)$ of juvenile (a) plaice (b) flounder and (c) sole, estimated from published and unpublished studies (see Table 1 for data sources) 
Table 2. Pleuronectes platessa, Platichthys flesus and Solea solea. Dynamic energy budget (DEB) model parameters at a species-specific reference temperature, and temperature dependence parameters for the 3 flatfish species. Whenever parameters differ between sexes, values for males are shown in (). For details on the notation used see Kooijman (2010)

\begin{tabular}{|lclccc|}
\hline Parameter & Units & \multicolumn{1}{c}{ Interpretation } & Plaice & Flounder \\
\hline$T_{1}$ & $\mathrm{~K}$ & Reference temperature & 283 & 283 & Sole \\
$V$ & $\mathrm{~cm} \mathrm{~d}^{-1}$ & Energy conductance & 0.156 & 0.156 & 0.435 \\
$g$ & - & Energy investment ratio & $2.635(3.930)$ & $3.590(4.211)$ & $3.111(3.684)$ \\
$k_{\mathrm{M}}$ & $\mathrm{d}^{-1}$ & Maintenance rate coefficient & 0.0035 & 0.0035 & 0.0097 \\
$L_{\mathrm{m}}$ & $\mathrm{cm}$ & Maximum physical length & $78(52)$ & $56(47)$ & $75(64)$ \\
$\delta_{\mathrm{M}}$ & - & Shape coefficient & 0.219 & 0.224 & 0.192 \\
$T_{\mathrm{A}}$ & $\mathrm{K}$ & Arrhenius temperature & 7000 & 7500 & 6500 \\
$T_{\mathrm{L}}$ & $\mathrm{K}$ & Lower boundary of tolerance range & 277 & 277 & 283 \\
$T_{\mathrm{H}}$ & $\mathrm{K}$ & Upper boundary of tolerance range & 295 & 296 & 301 \\
$T_{\mathrm{AL}}$ & $\mathrm{K}$ & Rate of decrease at lower boundary & 50000 & 35000 & 35000 \\
$T_{\mathrm{AH}}$ & $\mathrm{K}$ & Rate of decrease at upper boundary & 75000 & 75000 & 50000 \\
\hline
\end{tabular}

throughout the season with the exception of Mondego Estuary (southern Europe), where autumn growth rates in sole were still considerably high.

\section{DEB predictions and RG}

DEB parameters are summarized in Table 2. As expected, maximum growth rates predicted by the DEB model differed among sexes, with higher values for females. Overall, DEB parameter sets appeared to be reliable, as the resulting growth rates at various temperatures were in the same order of magnitude from those established in the laboratory and reproduced a similar temperature effect (Fig. 2). For plaice and flounder, DEB simulations for males were close to experimental growth, but for females, predictions were higher, particularly in plaice (Fig. 2).

In general, RG decreased over time, indicating an increasing discrepancy between field growth and model predictions. For plaice, most areas had similar patterns with relatively higher values in the beginning of the season, followed by a continuous decrease over time or stabilization, as observed in the Balgzand (Fig. 3a). The only exception was France, where RG seemed to increase over the course of time. Similar temporal dynamics were observed in

Fig. 2. Pleuronectes platessa, Platichthys flesus and Solea solea. Maximum daily growth of juvenile (a) plaice, (b) flounder and (c) sole under optimal food conditions in relation to water temperature. Growth predictions based on laboratory-derived models are indicated by filled circles (in a,b: - = Fonds et al. 1992; in c: $\mathbf{0}$ = Fonds \& Rijnsdorp 1988, = Irvin 1973 in Howell 1997). Lines: DEB model predictions for females (solid) and males (dashed)
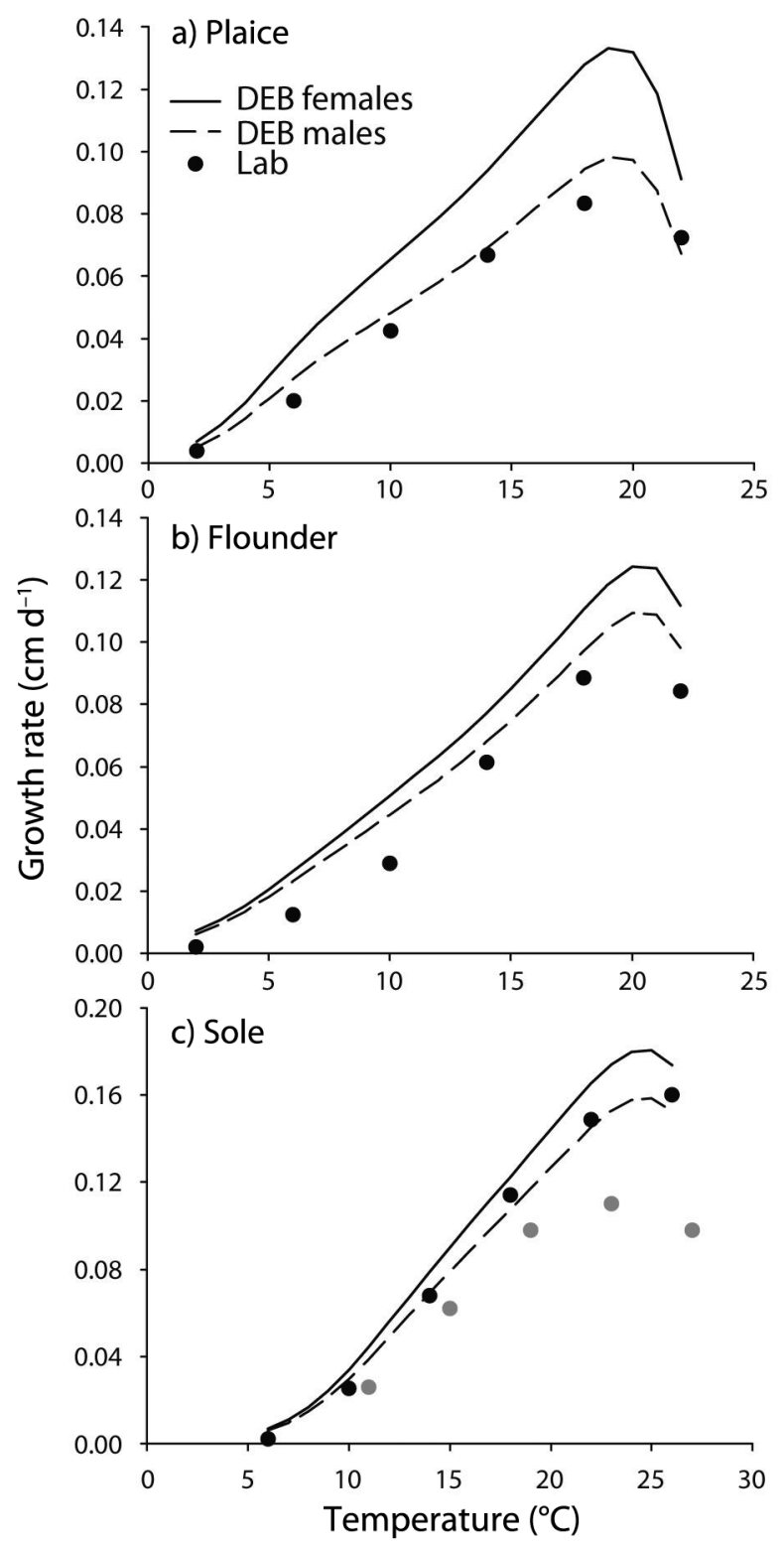

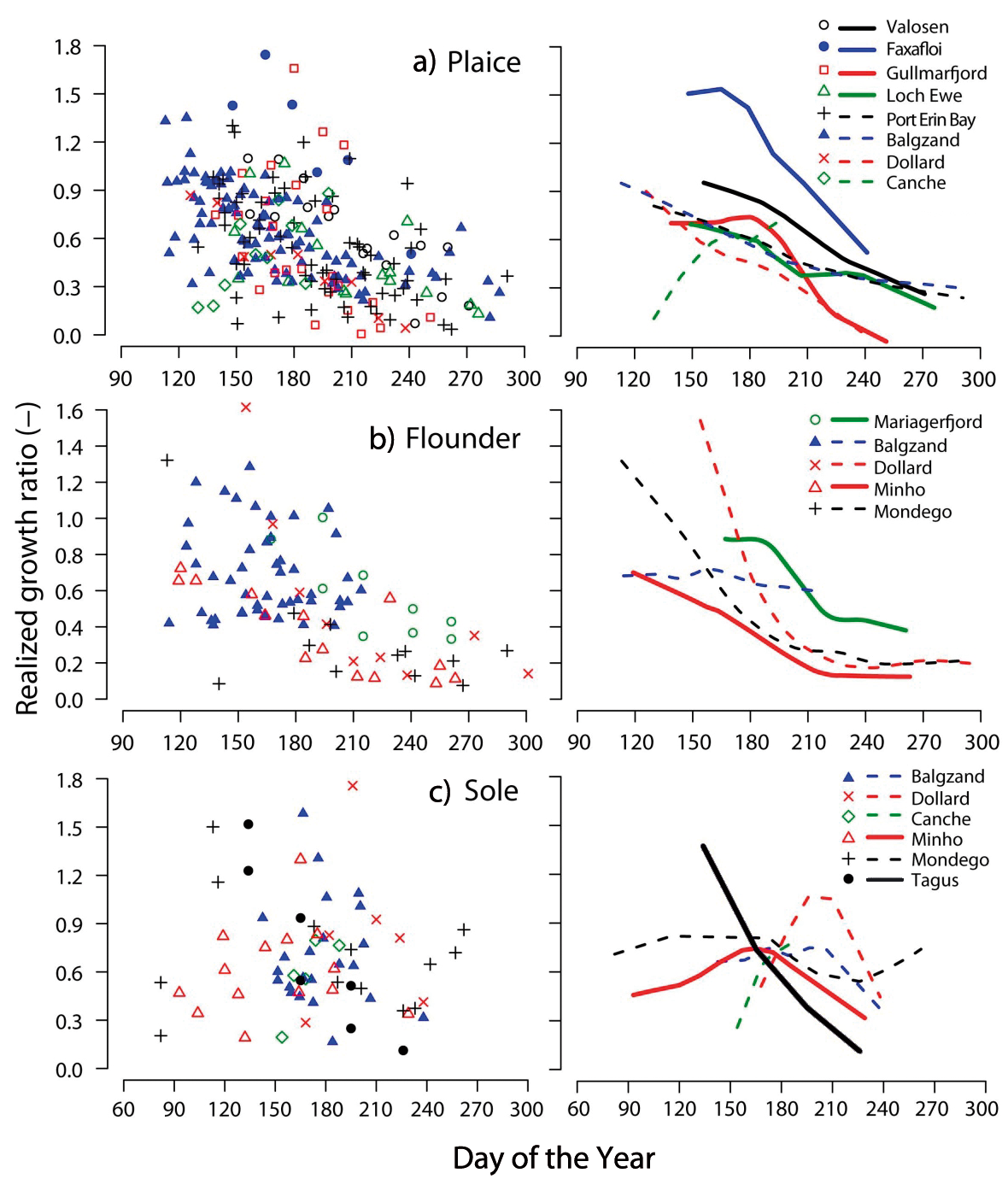

Fig. 3. Pleuronectes platessa, Platichthys flesus and Solea solea. Realized growth ratio estimates (left column) for (a) plaice (b) flounder and (c) sole. Values were averaged for females and males. Smoothing curves were added for each area to capture patterns in realized growth ratio over time (right column)

flounder (Fig. 3b), with steep declines in RG over time, followed by stabilization at around the end of July. In Balgzand, no clear change was observed with time and field growth rates were $\sim 70 \%(\mathrm{RG}=0.7)$ of the potential growth. Sole showed a more variable pattern compared with the other 2 species (Fig. 3C). Tagus Estuary was the only site with a clear and continuous decrease in RG over time. In the remaining areas, dome-shaped patterns were observed, with higher differences in observed relative to potential growth rates at both the beginning and end of the season. In Mondego Estuary, there was an additional increase in RG in early autumn.

Latitudinal comparisons of RG were made for each species separately. To account for different colonization periods among areas, comparisons were made for each month (May to September) using the predicted values from the smooth curves (Fig. 4). The RG of plaice and flounder exhibited clear positive trends with latitude from June to $\mathrm{Au}$ gust. In September, values were similar among locations, ranging from 20 to $40 \%$ of maximum potential growth. In sole, the same tendency was observed during July and August, with higher RG in northern compared with southern nurseries. In June, however, the trend was reversed, indicating close to maximum field growth rates in southern areas and lower than expected growth at higher latitudes (Eastern Channel and Balgzand).

Differences among nurseries were highest in June in plaice and flounder, as shown by steep regression lines that progressively decreased towards the end of the growing season (Fig. 4). In sole, differences between areas were largest in July.

\section{DISCUSSION}

\section{Habitat quality of flatfish nursery areas}

Shallow soft-bottom areas are assumed to provide abundant food supply to epibenthic assemblages (Evans 1983). This conjecture is supported by an enhanced diversity and abundance of macrobenthic fauna in flatfish nursery grounds compared with adjacent nonnursery areas (Wouters \& Cabral 2009).

Using a mechanistic approach for capturing growth dynamics, the present study challenges the assumption of stability in food conditions and supports previous indications that habitat quality in terms of growth conditions changes over the season, not only for plaice but also flounder, and that this pattern is common to several nurseries. Similar temporal dynamics, with a progressive deterioration of growth conditions throughout summer, have been observed for juvenile plaice in Tralee Beach and Loch Caolisport Beach, western Scotland, using an RNA-based growth index (Ciotti et al. 2010). The agreement in results using different methods seems to support a widespread phenomenon of food limitation. 
a) Plaice

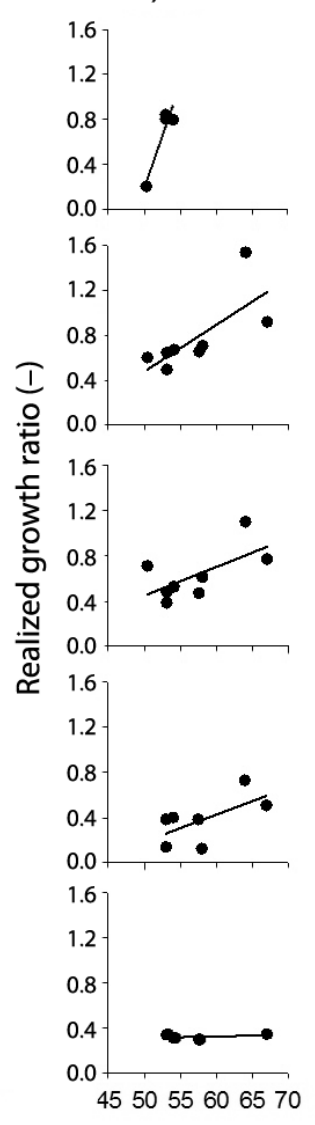

b) Flounder
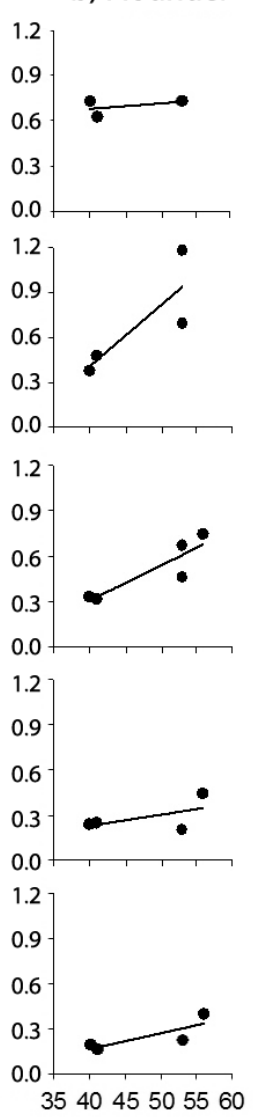

Latitude $\left({ }^{\circ} \mathrm{N}\right)$ c) Sole
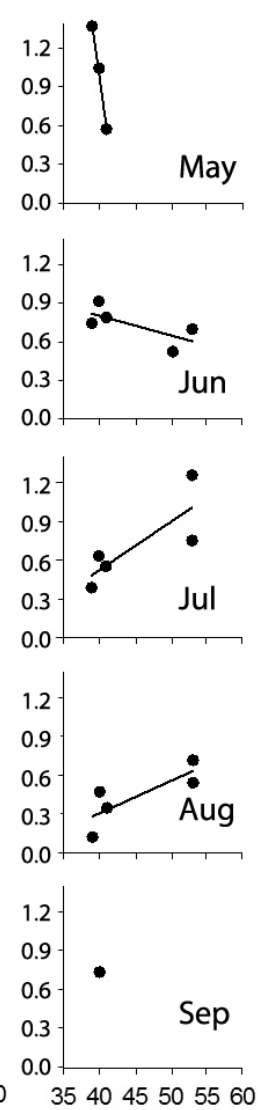

354045505560

Fig. 4. Pleuronectes platessa, Platichthys flesus and Solea solea. Relationship between realized growth ratio in each month and latitude for juvenile (a) plaice (b) flounder and (c) sole. Values were averaged for females and males. Regression lines were added to visualize trends

Available resources can be affected by exploitative competition between individuals, either of the same or different species. Studies with plaice point to a lack of intraspecific competition for food (Van der Veer et al. 2010) and for Irish Sea populations, it is even suggested that the carrying capacity of nursery grounds for plaice is rarely approached (Nash et al. 2007). However, interactions within the benthicfeeder assemblage (other fish and invertebrates) can modify the carrying capacity and trajectories for individual species (Gibson 1994, Nash et al. 2007). An analysis similar to the one applied in this study has suggested that in sand gobies Pomatoschistus minutus occurring sympatrically with juvenile flatfish during summer, growth is close to the maximum possible across their distribution range (Freitas et al. 2011), suggesting a competitive advantage.

Maximum individual intake rates can also be reduced as a consequence of interference by other organisms, affecting prey searching, capturing or handling by flatfish (see Van der Veer et al. 2010). Predator presence, for instance, has been found to reduce feeding activity in plaice (Burrows \& Gibson 1995) and sole (Maia et al. 2009). Another example of interference competition reducing the amount of food available for juvenile flatfish is the browsing activity by other fish and crustaceans on bivalve and polychaete soft tissues (De Vlas 1979, 1985, Kamermans \& Huitema 1994), affecting prey quality (Bergman et al. 1988a, Zwarts \& Wanink 1989, Zajac 1995, De Goeij et al. 2001, Meyer \& Byers 2005).

The temporal trend in growth conditions observed in plaice and flounder was not exhibited by sole, which seems to suggest that even if the underlying mechanism is the same, responses cannot be generalized even within a functional group. Although the reasons are not clear, sole may avoid interspecific competition by spatial and temporal feeding activities (Besyst et al. 1999), for instance, taking advantage of its capacity to forage during the night as opposed to plaice and flounder, which are daytime feeders (Lagardère 1987, Besyst et al. 1999).

Our approach to analyse changes in habitat quality based on RG relies on the premise of accurate characterization of both field growth and temperature conditions experienced. This study builds on previous research, taking advantage of available data, which invariably describe growth from changes in modal or mean length of sampled populations rather than from individual trajectories. These estimates are known to be influenced by migration, gear efficiency and sizeselective mortality. Although ideally one could avoid some bias associated with migrations by considering only the period once settlement is completed and before the autumn migrations to deeper waters start, this time window is probably nursery-ground-dependent (Nash et al. 2007), making the comparison between areas more complicated. Therefore, a more general criterion for data selection had to be used. By restricting the analyses to a period where a more or less linear increase in size was observed, we have tried to preclude inaccurate estimations, which would affect the evaluation of realized growth.

Some of the discrepancy between field and maximum predicted growth rates can be related to an inaccurate representation of field temperature conditions. As a result of fine-scale habitat selection among juveniles, the thermal regime experienced by the population may differ from the temperature recorded in the field (Hurst et al. 2010). In some cases, 
this could result in RG values larger than 1 if, for instance, juveniles tend to select warmer locations early in the season (Fig. 3).

\section{Latitudinal trends}

The temporal dynamics in realized growth within each area complicates a latitudinal comparison of habitat quality for the various species. Nevertheless, our results seem to indicate a consistent positive latitudinal trend during summer in all 3 species studied. Despite the suggestion for lower benthic biomass and production at lower latitudes (Pauly 1994), evidence from a few European nurseries does not seem to support such a trend, instead indicating similar biomass figures (Beukema et al. 2002, Wouters \& Cabral 2009, Freitas et al. 2010a). From a bioenergetics viewpoint, assuming that food conditions are generally similar, energy uptake must be higher in order to compensate for extra metabolic costs at southern, warmer locations. In the presence of competition, southern areas are thus more prone to food limitation, as individual energy intake is likely to be reduced compared with more northern areas.

We have observed a downward shift in RG patterns from northern to southern areas, which supports this competition hypothesis. The results for sole are particularly indicative of how this mechanism may act: in the beginning of the growing season, the RG of sole is higher in southern compared with northern areas; however, throughout the season this pattern inverses. In contrast to northern European areas where sole only occur after plaice and flounder have settled (Jager et al. 1995, Amara et al. 2001, Van der Veer et al. 2001a), in southern European nurseries, sole juveniles are the first marine species to colonize these areas, appearing in April-May (Cabral 2003, Dolbeth et al. 2010), and in some years, young-of-the-year can even be observed from late January onwards (Martinho et al. 2008). This could confer an advantage to sole by occupying an empty niche with ample food resources, which, combined with high summer temperatures, would allow for fast growth. Throughout the season, competition starts playing its role in reducing food availability and leading to the same spatial trends as observed in flounder and plaice.

Southern European nursery areas do not allow for maximum growth, neither in flounder nor in sole, in spite of the longer growing seasons which lead to larger juveniles by the end of the first year (Martinho et al. 2008). In the Tagus Estuary, food has not been considered a limiting factor for sole based on compar- isons of food consumption and prey biomass (Vinagre $\&$ Cabral 2008). Instead, thermal stress has been suggested as a possible cause for hampering growth rates in sole as summer temperatures largely exceed metabolic optimum temperatures (Vinagre et al. 2008). Excessive temperatures have also been suggested as the mechanism responsible for the drastic decline in flounder observed in recent years in this estuary (Cabral et al. 2001, 2007), and for a disruption in plaice recruitment in the Bay of Biscay (Désaunay et al. 2006, Hermant et al. 2010).

In the context of global warming, our results suggest that habitat quality of southern European nurseries for juvenile growth may be particularly affected by climatic changes through a combination of both food and thermal constraints. Our approach explicitly accounted for the thermal effects on growth rates. However, the parameters used to describe temperature dependence were taken as constant on both temporal and spatial scales. Temperature has such a pervasive effect on performance that organisms have certainly managed to respond to their thermal environment. These responses can vary from short-term organismal-level behavioural and physiological adjustments, to adaptive shifts within the lifetime of an individual (Angilleta et al. 2002) and, on the scale of multiple generations, genetic changes may occur (Bradshaw \& Holzapfel 2006). Differences in growth performance among flatfish populations and some evidence for latitudinal compensation in growth have already been demonstrated (Imsland et al. 2000, 2001, Jonassen et al. 2000). However, how much of this intraspecific variability translates into the energy budget and which model parameters are more likely to be affected still need to be clarified. Elucidating these aspects will bring us one step forward towards better predicting the responses in juvenile nursery quality to changes in climate.

Acknowledgements. The authors are indebted to Stig Skreslet (Faculty of Fisheries and Natural Sciences, Bodø University College, Norway) for providing working facilities during field campaigns in Norway, and to the team involved in fieldwork, namely Sílvia Santos, Jeremy Smith, Cindy Pedrosa, Hans Witte and Joana Campos. Thanks are due to Leif Pihl (Department of Marine Ecology, University of Gothenburg) and Richard Nash (Institute of Marine Research, Bergen) for providing unpublished data from Gullmarsfjord, Sweden, and Port Erin Bay, Isle of Man, respectively. V.F. was funded with a PhD grant from FCT (Fundação para a Ciência e a Tecnologia, Portugal). This study was in part supported by the Netherlands Organization for Scientific Research (NWO) via Project 83908241 of the National Programme Sea and Coastal Research (ZKO). 


\section{LITERATURE CITED}

Able KW, Manderson JP, Studholme AL (1999) Habitat quality for shallow water fishes in an urban estuary: the effects of man-made structures on growth. Mar Ecol Prog Ser 187:227-235

Amara R (2004) 0-group flatfish growth conditions on a nursery ground (Bay of Canche, Eastern English Channel). Hydrobiologia 518:23-32

> Amara R, Paul C (2003) Seasonal patterns in the fish and epibenthic crustaceans community of an intertidal zone with particular reference to the population dynamics of plaice and brown shrimp. Estuar Coast Shelf Sci 56: 807-818

Amara R, Laffargue P, Dewarumez JM, Maryniak C, Lagardere F, Luzac C (2001) Feeding ecology and growth of 0 group flatfish (sole, dab and plaice) on a nursery ground (Southern Bight of the North Sea). J Fish Biol 58:788-803

- Amara R, Meziane T, Gilliers C, Hermel G, Laffargue P (2007) Growth and condition indices in juvenile sole Solea solea measured to assess the quality of essential fish habitat. Mar Ecol Prog Ser 351:201-208

> Andersen BS, Carl JD, Grønkjær P, Støttrup JG (2005) Feeding ecology and growth of age 0 year Platichthys flesus (L.) in a vegetated and a bare sand habitat in a nutrient rich fjord. J Fish Biol 66:531-552

> Angilletta MJ Jr, Niewiarowski PH, Navas CA (2002) The evolution of thermal physiology in ectotherms. J Therm Biol 27:249-268

> Beck MW, Heck KL, Able KW, Childers DL and others (2001) The identification, conservation, and management of estuarine and marine nurseries for fish and invertebrates. Bioscience 51:633-641

- Bergman MJN, Van der Veer HW, Karczmarski L (1988a) Impact of tail-nipping on mortality, growth and reproduction of Arenicola marina. Neth J Sea Res 22:83-90

> Bergman MJN, Van der Veer HW, Zijlstra JJ (1988b) Plaice nurseries: effects on recruitment. J Fish Biol 33:201-218

Beukema JJ, Cadée GC, Dekker R (2002) Zoobenthic biomass limited by phytoplankton abundance: evidence from parallel changes in two long-term data series in the Wadden Sea. J Sea Res 48:111-125

> Beverton RJH, Iles TC (1992) Mortality rates of 0-group plaice (Pleuronectes platessa L), dab (Limanda limanda L.) and turbot (Scophthalmus maximus L.) in European waters II. Comparison of mortality rates and constructton of life table for 0-group plaice. Neth J Sea Res 29:49-59

> Besyst B, Cattrijsse A, Mees J (1999) Feeding ecology of juvenile flatfishes of the surf zone of a sandy beach. J Fish Biol 55:1171-1186

> Bradshaw WE, Holzapfel CM (2006) Evolutionary response to rapid climate change. Science 312:1477-1478

> Brandt SB (1993) The effect of thermal fronts on fish growth: a bioenergetics evaluation of food and temperature. Estuaries 16:142-159

> Burrows MT, Gibson RN (1995) The effects of food, predation risk and endogenous rhythmicity on the behaviour of juvenile plaice, Pleuronectes platessa L. Anim Behav 50:41-52

> Cabral H (2003) Differences in growth rates of juvenile Solea solea and Solea senegalensis in the Tagus estuary, Portugal. J Mar Biol Assoc UK 83:861-868

Cabral HN, Costa MJ (2001) Abundance, feeding ecology and growth of 0-group sea bass Dicentrarchus labrax, within the nursery area of the Tagus estuary. J Mar Biol
Assoc UK 81:679-682

> Cabral HN, Costa MJ, Salgado JP (2001) Does the Tagus estuary fish community reflect environmental changes? Clim Res 18:119-126

Cabral HN, Vasconcelos RP, Vinagre C, França S and others (2007) Relative importance of estuarine flatfish nurseries along the Portuguese coast. J Sea Res 57:209-217

Ciotti BJ, Targett TE, Nash RDM, Batty RS, Burrows MT, Geffen AJ (2010) Development, validation and field application of an RNA-based growth index in juvenile plaice Pleuronectes platessa. J Fish Biol 77:2181-2209

> Cowley PD, Whitfield AK (2002) Biomass and production estimates of a fish community in a small South African estuary. J Fish Biol 61:74-89

De Goeij P, Luttikhuizen PC, van der Meer J, Piersma T (2001) Facilitation on an intertidal mudflat: the effect of siphon nipping by flatfish on burying depth of the bivalve Macoma balthica. Oecologia 126:400-506

> De Vlas J (1979) Annual food intake by plaice and flounder in a tidal flat area in the Dutch Wadden Sea, with special reference to consumption of regenerating parts of macrobenthic prey. Neth J Sea Res 13:117-153

> De Vlas J (1985) Secondary production by siphon regeneration in a tidal flat population of Macoma balthica. Neth J Sea Res 19:147-164

> Désaunay Y, Guérault D, Le Pape O, Poulard JC (2006) Changes in occurrence and abundance of northern/ southern flatfishes over a 20-year period in a coastal nursery area (Bay of Vilaine) and on the eastern continental shelf of the Bay of Biscay. Sci Mar 70:193-200

> Dolbeth M, Martinho F, Freitas V, Costa-Dias S, Campos J, Pardal MA (2010) Multi-year comparisons of fish recruitment, growth and production in two drought-affected Iberian estuaries. Mar Freshw Res 61:1399-1415

Edwards R, Steele JH (1968) The ecology of 0-group plaice and common dabs at Loch Ewe. I. Population and food. J Exp Mar Biol Ecol 2:15-38

- Evans S (1983) Production, predation and food niche segregation in a marine shallow soft-bottom community. Mar Ecol Prog Ser 10:147-157

Fonds M, Rijnsdorp AD (1988) Eten and groeien. In: Osse JWM, Zijlstra JJ, Van Emden HM (eds) Als een Vis in the Water. Pudoc, Wageningen, p 120-138

Fonds M, Cronie R, Vethaak AD, Van der Puyl P (1992) Metabolism, food consumption and growth of plaice (Pleuronectes platessa) and flounder (Platichthys flesus) in relation to fish size and temperature. Neth J Sea Res 29:127-143

Freitas V, Campos J, Skreslet S, Van der Veer HW (2010a) Habitat quality of a subarctic nursery ground for 0-group plaice (Pleuronectes platessa L.). J Sea Res 64:26-33

Freitas V, Cardoso JFMF, Lika K, Peck MA, Campos J, Kooijman SALM, Van der Veer HW (2010b) Temperature tolerance and energetics: a dynamic energy budgetbased comparison of North Atlantic marine species. Philos Trans R Soc Lond B 365:3553-3565

Freitas V, Lika K, Witte JIJ, Van der Veer HW (2011) Food conditions of the sand goby Pomatoschistus minutus in shallow waters: an analysis in the context of dynamic energy budget theory. J Sea Res 66:440-446

> Gibson RN (1994) Impact of habitat quality and quantity on the recruitment of juvenile flatfishes. Neth J Sea Res 32: 191-206

Gibson RN, Robb L, Wennhage H, Burrows MT (2002) Ontogenetic changes in depth distribution of juvenile flat- 
fishes in relation to predation risk and temperature on a shallow-water nursery ground. Mar Ecol Prog Ser 229: 233-244

> Henderson PA, Seaby RM, Somes JR (2006) A 25-year study of climatic and density-dependent population regulation of common shrimp Crangon crangon (Crustacea: Caridea) in the Bristol Channel. J Mar Biol Assoc UK 86: 287-298

> Hermant M, Lobry J, Bonhommeau S, Poulard JC, Le Pape O (2010) Impact of warming on abundance and occurrence of flatfish populations in the Bay of Biscay (France). J Sea Res 64:45-53

> Hjörleifsson E, Pálsson J (2001) Settlement, growth and mortality of 0-group plaice (Pleuronectes platessa) in Icelandic waters. J Sea Res 45:321-324

- Howell BR (1997) A re-appraisal of the potential of the sole, Solea solea (L.), for commercial cultivation. Aquaculture 155:355-365

Hurst TP, Abookire AA (2006) Temporal and spatial variation in potential and realized growth rates of age-0 year northern rock sole. J Fish Biol 68:905-919

> Hurst TP, Abookire AA, Knoth B (2010) Quantifying thermal effects on contemporary growth variability to predict responses to climate change in northern rock sole (Lepidopsetta polyxystra). Can J Fish Aquat Sci 67:97-107

Imsland AK, Foss A, Næevdal G, Cross T, Bonga SW, van Ham E, Stefansson SO (2000) Countergradient variation in growth and food conversion efficiency of juvenile turbot. J Fish Biol 57:1213-1226

Imsland AK, Foss A, Stefansson SO (2001) Variation in food intake, food conversion efficiency and growth of juvenile turbot from different geographic strains. J Fish Biol 59: 449-454

Jager Z, Kleef HL, Tydeman P (1995) Mortality and growth of 0-group flatfish in the brackish Dollard (Ems estuary, Wadden Sea). Neth J Sea Res 34:119-129

> Jonassen TM, Imsland AK, FitzGerald R, Stefánsson MÖ and others (2000) Geographic variation in growth and growth efficiency of juvenile Atlantic halibut related to latitude. J Fish Biol 56:279-294

> Kamermans P, Huitema HJ (1994) Shrimp (Crangon crangon L.) browsing upon siphon tips inhibits feeding and growth in the bivalve Macoma balthica (L.). J Exp Mar Biol Ecol 175:59-75

Kooijman SALM (2000) Dynamic energy and mass budgets in biological systems. Cambridge University Press, Cambridge

Kooijman SALM (2010) Dynamic energy budget theory for metabolic organization. Cambridge University Press, Cambridge

> Lagardère JP (1987) Feeding ecology and daily food consumption of common sole, Solea vulgaris Quensel, juveniles on the French Atlantic coast. J Fish Biol 30:91-104

Le Pape O, Holley J, Guérault D, Désaunay Y (2003) Quality of coastal and estuarine essential fish habitats: estimations based on the size of juvenile common sole (Solea solea L.). Estuar Coast Shelf Sci 58:793-803

> Maes J, Taillieu A, Van Damme PA, Cottenie K, Ollevier FP (1998) Seasonal patterns in the fish and crustacean community of a turbid temperate estuary (Zeeschelde Estuary, Belgium). Estuar Coast Shelf Sci 47:143-151

- Maia A, Vinagre C, Cabral HN (2009) Impact of a predator in the foraging behaviour of Solea senegalensis. J Mar Biol Assoc UK 89:645-649

Martinho F, Leitao R, Neto JM, Cabral H, Lagardere F,
Pardal MA (2008) Estuarine colonization, population structure and nursery functioning for 0-group sea bass (Dicentrarchus labrax), flounder (Platichthys flesus) and sole (Solea solea) in a mesotidal temperate estuary. J Appl Ichthyol 24:229-237

Meyer JJ, Byers JE (2005) As good as dead? Sublethal predation facilitates lethal predation on an intertidal clam. Ecol Lett 8:160-166

Nash RDM, Geffen AJ, Hughes G (1994) Individual growth of juvenile plaice (Pleuronectes platessa L.) on a small Irish Sea nursery ground (Port Erin Bay, Isle of Man, UK). Neth J Sea Res 32:369-378

Nash RDM, Geffen AJ, Burrows MT, Gibson RN (2007) Dynamics of shallow-water juvenile flatfish nursery grounds: application of the self-thinning rule. Mar Ecol Prog Ser 344:231-244

Nielsen JG (1986) Pleuronectidae. In: Whitehead PJP, Bauchot ML, Hureau JC, Nielsen J, Tortonese E (eds) Fishes of the North-eastern Atlantic and Mediterranean. United Nations Educational, Scientific and Cultural Organization, Paris, p 1299-1307

Pauly D (1994) A framework for latitudinal comparisons of flatfish recruitment. Neth J Sea Res 32:107-118

Pihl L (1985) Food selection and consumption of mobile epibenthic fauna in shallow marine areas. Mar Ecol Prog Ser 22:169-179

Quéro JC, Desoutter M, Lagardère F (1986) Soleidae. In: Whitehead PJP, Bauchot ML, Hureau JC, Nielsen J, Tortonese E (eds) Fishes of the North-eastern Atlantic and Mediterranean. United Nations Educational, Scientific and Cultural Organization, Paris, p 1308-1324

R Development Core Team (2009) R: A language and environment for statistical computing. R Foundation for Statistical Computing, Vienna, Austria. www.R-project.org

Rijnsdorp AD, Van Beek FA, Flatman S, Millner RM, Riley JD, Giret M, De Clerck R (1992) Recruitment of sole stocks, Solea solea (L.), in the Northeast Atlantic. Neth J Sea Res 29:173-192

Sinclair M (1988) Marine populations. An essay on population regulation and speciation. University of Washington Press, Seattle, WA

Sogard SM (1997) Size-selective mortality in the juvenile stage of teleost fishes: a review. Bull Mar Sci 60:1129-1157

Steele JH, Edwards RRC (1970) The ecology of 0-group plaice and common dabs in Loch Ewe. IV. Dynamics of the plaice and dab populations. J Exp Mar Biol Ecol 4: 174-187

Teal LR, De Leeuw JJ, Van der Veer HW, Rijnsdorp AD (2008) Effects of climate change on growth of 0-group sole and plaice. Mar Ecol Prog Ser 358:219-230

Van der Veer HW (1986) Immigration, settlement, and density-dependent mortality of a larval and early postlarval 0 -group plaice (Pleuronectes platessa) population in the western Wadden Sea. Mar Ecol Prog Ser 29:223-236

- Van der Veer HW, Bergman MJN, Dapper R, Witte JIJ (1991) Population dynamics of an intertidal 0-group flounder Platichthys flesus population in the western Dutch Wadden Sea. Mar Ecol Prog Ser 73:141-148

Van der Veer HW, Berghahn R, Rijnsdorp AD (1994) Impact of juvenile growth on recruitment in flatfish. Neth J Sea Res 32:153-173

Van der Veer HW, Berghahn R, Miller JM, Rijnsdorp AD (2000) Recruitment in flatfish, with special emphasis on North Atlantic species: progress made by the Flatfish Symposia. ICES J Mar Sci 57:202-215 
Van der Veer HW, Dapper R, Witte JIJ (2001a) The nursery function of the intertidal areas in the western Wadden Sea for 0-group sole Solea solea (L.). J Sea Res 45:271-279

> Van der Veer HW, Kooijman SALM, Van der Meer J (2001b) Intra-and interspecies comparison of energy flow in North Atlantic flatfish species by means of dynamic energy budgets. J Sea Res 45:303-320

- Van der Veer HW, Cardoso JFMF, Peck MA, Kooijman SALM (2009) Physiological performance of plaice Pleuronectes platessa (L.): A comparison of static and dynamic energy budgets. J Sea Res 62:83-92

> Van der Veer HW, Freitas V, Koot J, Witte JIJ, Zuur AF (2010) Food limitation in epibenthic species in temperate intertidal systems in summer: analysis of 0-group plaice Pleuronectes platessa. Mar Ecol Prog Ser 416:215-227

Vasconcelos RP, Reis-Santos P, Costa MJ, Cabral HN (2011) Connectivity between estuaries and marine environment: Integrating metrics to assess estuarine nursery function. Ecol Indic 11:1123-1133

> Viegas I, Martinho F, Neto J, Pardal M (2007) Population dynamics, distribution and secondary production of the brown shrimp Crangon crangon (L.) in a southern European estuary. Latitudinal variations. Sci Mar 71:451-460
Vinagre C, Cabral HN (2008) Prey consumption by the juvenile soles, Solea solea and Solea senegalensis, in the Tagus estuary, Portugal. Estuar Coast Shelf Sci 78:45-50

> Vinagre C, Franca S, Costa MJ, Cabral HN (2005) Niche overlap between juvenile flatfishes, Platichthys flesus and Solea solea, in a southern European estuary and adjacent coastal waters. J Appl Ichthyology 21:114-120

- Vinagre C, Amara R, Maia A, Cabral HN (2008) Latitudinal comparison of spawning season and growth of 0-group sole, Solea solea (L.). Estuar Coast Shelf Sci 78:521-528

Wouters N, Cabral HN (2009) Are flatfish nursery grounds richer in benthic prey? Estuar Coast Shelf Sci 83:613-620

Zajac RN (1995) Sublethal predation on Polydora cornuta (Polychaeta: Spionidae): patterns of tissue loss in a field population, predator functional response and potential demographic impacts. Mar Biol 123:531-541

> Zijlstra JJ, Dapper R, Witte JIJ (1982) Settlement, growth and mortality of post-larval plaice (Pleuronectes platessa L.) in the western Wadden Sea. Neth J Sea Res 15: $250-272$

Zwarts L, Wanink J (1989) Siphon size and burying depth in deposit- and suspension-feeding benthic bivalves. Mar Biol 100:227-240 


\section{Appendix 1}
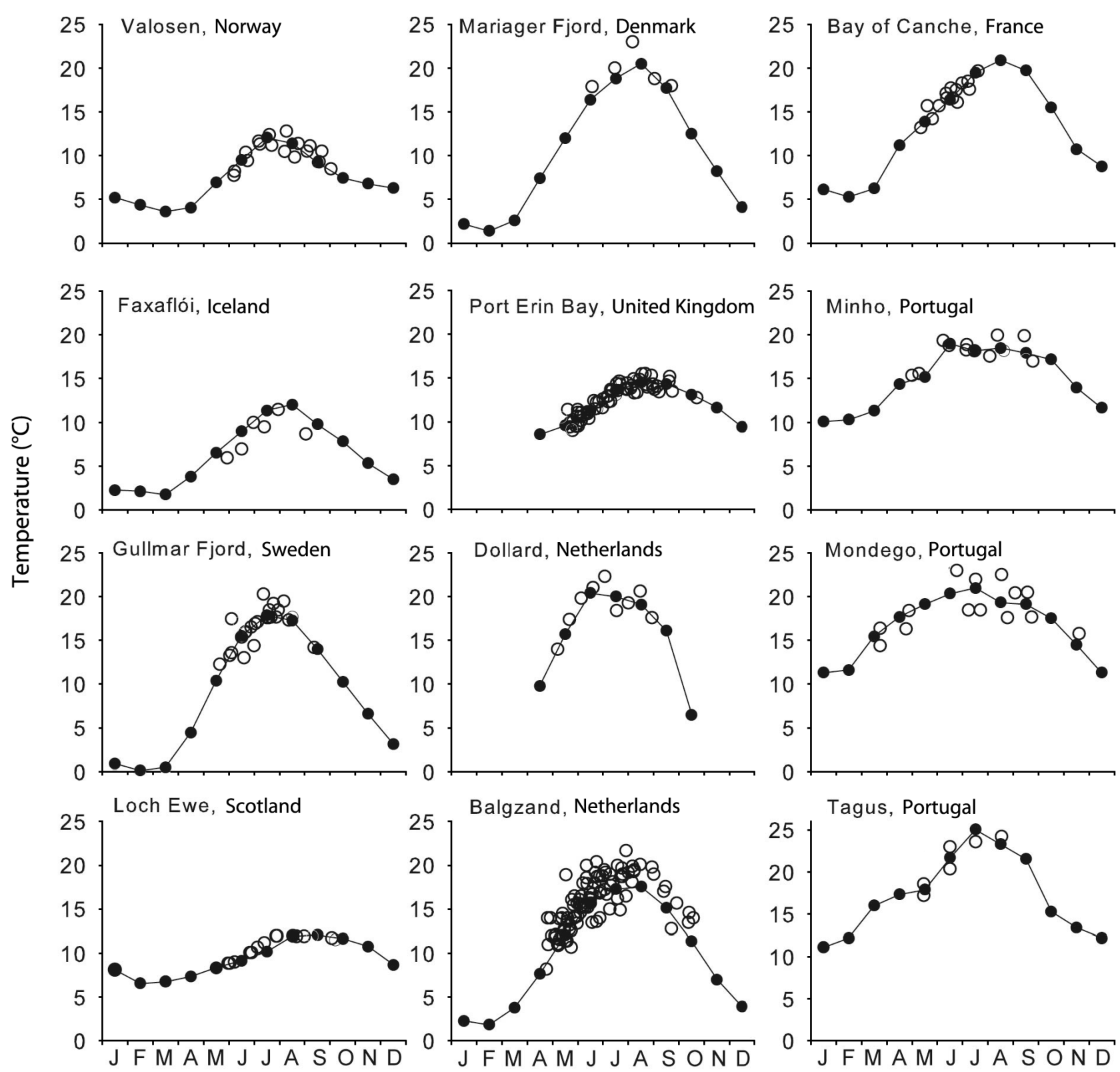

Fig. A1. Average monthly water temperatures $(\bullet)$ recorded at the various locations, compiled from the original published studies or oceanographic data centres. For data sources, see Table 1. O: temperature values used to estimate maximum growth rates

Editorial responsibility: Stylianos Somarakis, Heraklion, Greece
Submitted: January 9, 2012; Accepted: August 28, 2012 Proofs received from author(s): November 26, 2012 